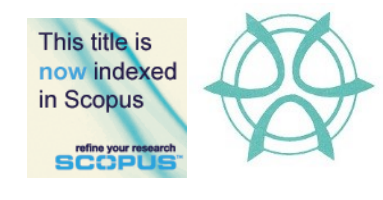

\title{
FIRST-TIME HOMEBUYERS' INTERESTS IN USING PROPERTY CROWDFUNDING AS AN ALTERNATIVE FINANCING OPTION
}

\author{
Hon-Choong Chin ${ }^{1}$, Sheelah Sivanathan ${ }^{2}$, Goh Hong Lip ${ }^{3}$ \& Low Choon \\ $\mathrm{Wei}^{4}$ \\ ${ }^{1}$ Department of Building \& Property Management, Faculty of Accountancy and \\ Management, UNIVERSITI TUNKU ABDUL RAHMAN \\ ${ }^{2}$ Department of Economics, Faculty of Accountancy and Management, \\ UNIVERSITI TUNKU ABDUL RAHMAN
}

\begin{abstract}
Property crowdfunding as an alternative financing option for first-time homebuyers was introduced by the Malaysian government during the presentation of the National Budget 2019. This platform was the first of its kind, and targeted fundraisers who were first-time homebuyers, i.e., those allowed to raise financial support for their home purchase via the platform. As the mechanism of the Malaysian property crowdfunding platform is new to homebuyers, this study aims to explore homebuyers' interests to use property crowdfunding platform as an alternative financing option for the purchase of their first home. First-time homebuyers' opinions were collected through face-to-face interviews, and content analysis was performed to analyse the obtained qualitative data. Key themes were identified and organised into three sections: (i) knowledge of the property crowdfunding; (ii) factors that motivated the use of the property crowdfunding and (iii) barriers that hindered the use of the property crowdfunding. These findings are expected to contribute toward the adoption of the property crowdfunding in Malaysia.
\end{abstract}

Keywords: property crowdfunding, first-time homebuyer, affordable housing, homeownership

\footnotetext{
${ }^{1}$ Assistant Professor at Universiti Tunku Abdul Rahman Email: chinhc@utar.edu.my
} 
PLANNING MALAYSIA

Journal of the Malaysia Institute of Planners (2021)

\section{INTRODUCTION}

As an alternative financial scheme, crowdfunding has received increasing attention worldwide. The concept of crowdfunding has been adopted as an alternative financing option for new ventures, as well as cultural and social projects (Mollick, 2014). In general, crowdfunding is a micro-finance concept (Mollick, 2014) based on the fundraising strategy which collects an individual's small amount of capital from across a large group of people (Ordanini et al., 2011; Sigar, 2012). It connects the investees (project or idea owners) with potential supporters for the purpose of turning start-up ideas into reality (Ramsey, 2012). Thus, it involves three main participants which are the fund seekers (project or idea owners), investors, and the platform operators.

In terms of the business models, there are four types of crowdfunding platforms, namely donation-based, reward-based, equity-based and loan-based (Massolution, 2015). In general, the donation-based platform is used by nonprofit organisations for charity purposes, while the reward-based platform is offered to the crowd funders as a token of appreciation in recognition of their business ideas. In contrast, the equity-based and loan-based platforms are investment oriented, in the sense that they fund providers who are looking toward for a return from their investments. Similarly, in the real estate domain, property crowdfunding is a fundraising process, whereby developers and project owners raise an aggregated small amount of capital from a large group of individual investors via the internet platform (Maarbani, 2015). The business model of property crowdfunding platform is either equity-based, or loan-based. It allows the investor and property developer (the project owners) to achieve a higher interest by eliminating the involvement of intermediaries and transaction costs (Miller, 2015). Although the crowdfunding concept has been widely adopted, studies on the application of this concept in the real estate domain has remained scarce (Lowies, Viljoen and McGreal, 2017). The application of the crowdfunding concept in the real estate industry is worth being investigated, as both the risk and the growth opportunity needed to be clarified (Cohen, 2016).

The importance of crowdfunding as an alternative financial platform has been recognised in Malaysia for some time now. In fact, Malaysia is the first country within the Asia-Pacific Region to legislate an equity-based and peer-topeer lending crowdfunding platform (Mokhtarrudin, Masrurah, and Muhamad, 2017). According to the Asian Institute of Finance (2017), there was a total of RM15.8 million funds which were raised using equity-based platforms to support 24 projects, and the amount of funds were expected to increase to RM343.4 million by 2021. On the other hand, peer-to-peer crowdfunding platforms are expected to secure RM1513.7 million in funding by 2021. Recently, the application of crowdfunding had been further embraced by the Malaysian government to support homeownership. As stated in the Malaysian 2019 national budget, property crowdfunding had been introduced by the Malaysian 
Hon-Choong Chin, Sheelah Sivanathan, Goh Hong Lip \& Low Choon Wei

First-Time Homebuyers' Interest in Using Property Crowdfunding as An Alternative Financing Option

government as an alternative financing option for first time homebuyers (Ministry of Finance, 2018). It is recognised that by promoting an innovative home financing product will certainly offer benefits in term of promoting homeownership in Malaysia (Mohd Yusof et al., 2019), as it provides an alternative pathway that increases the possibilities for those who need access to financial assistance (Yusof et al., 2019), as well as addressing the mismatch between the existing financial system criteria and the homebuyer's profile (Kamal et al., 2018). It is worth mentioning that difficulties in obtaining housing loans have contributed to the failure of homeownership, especially those in lowand medium-income groups (Hing and Singaravelloo, 2018; Osman et al., 2020).

Unlike traditional property crowdfunding platforms which are predominantly used to raise funds for property development projects, the recently announced Malaysian property crowdfunding platform is meant to address housing affordability issues, and facilitate homeownership among first time homebuyers. Accordingly, under the Malaysia property crowdfunding mechanism, first time homebuyers can secure a property by paying $20 \%$ of the property selling price, as the remaining $80 \%$ will be funded by potential investors who are keen to fund the property in exchange for the potential appreciation in the future property value. Recently, the $20 \%$ deposit had been allowed to be reduced to $10 \%$ by the Securities Commission of Malaysia. By doing so, the financial burden of owning a house had been reduced, thus, making homeownership an affordable option for homebuyers.

In recognising the potential of property crowdfunding platform as an alternative financing option, studies have disclosed the associated advantages and disadvantages (Vogel and Moll, 2014) as well as the risks and potential growth associated with the property crowdfunding platform (Cohen, 2016), which highlighted the concerns over information asymmetry pertaining to the investment decision via property crowdfunding (Ahlers et al., 2015). It also investigated the influence of the characteristics of property, financial and crowdfunding platform characteristics on the return of the property platform (Schweizer and Zhou, 2016), which identified investors as the key driving factor for change (O'Roarty et al., 2016), and profiled the investor's risk perceptions (Lowies et al., 2017). Nonetheless, these studies have been focused on the investment perspective whereby policy implication is now focused on promoting investment decision-making using property crowdfunding platforms. Studies on another domain, which is the user's perspective has remained scare, and is worth being investigated as the key to the success of the property crowdfunding platform, which does not solely depend on the investor's interest to invest, but, also on the intention of the users (fundraisers) to adopt the platform as an alternative financing option for them. 
PLANNING MALAYSIA

Journal of the Malaysia Institute of Planners (2021)

Furthermore, the Malaysian property crowdfunding is novel compared to that of the traditional property crowdfunding platforms, in such a way that fundraisers are the homebuyers, instead of developers and project owners. This makes the Malaysian property crowdfunding platform the first of its kind in the world, whereby, it serves as a platform for homebuyers to seek financial capital to purchase their homes. Following this, the motive of using the property crowdfunding platform is very much different, as developers and project owners (in the traditional property crowdfunding platform mechanism) intend to seek funds to support their development projects for businesses and investment purposes, while, homeowners (in the case of the Malaysian property crowdfunding platform) intend to secure financial support for personal homeownership purposes. In addition to that, the investment based crowdfunding platform (such as the property crowdfunding platform in this study) is unique and different from other forms of crowdfunding platforms, due to the differences in term of its incentives and compensation (Hervé et al., 2017). This uniqueness further points to the fact that the adoption of crowdfunding platforms can be case specific, whereby the user's motive for a crowdfunding platform can be distinguished and differ from other crowdfunding platforms. In other words, the Malaysian homebuyer's intentions to use property crowdfunding platforms can differ from that of users from other countries and regions, which use different forms of crowdfunding platforms to facilitate homeownership. On top of that, property crowdfunding is regarded as a potentially disruptive innovation which may disrupt the traditional real estate finance market (Montgomery, Squires and Syed, 2018). Thus, understanding the homebuyer's intentions to use property crowdfunding as an alternative financing vehicle can contribute toward the preparation of the industry for facing the adoption challenges of this disruptive innovation. In short, this study not only contributes toward the scarcity of literature on property crowdfunding, but also prepares the Malaysian real estate industry and financial industry for addressing the challenges pertaining to property crowdfunding adoption, by-providing an in-depth understanding of the Malaysian homebuyer's intentions to use the property crowdfunding platform as an alternative financing option to secure their homeownership.

\section{RESEARCH METHOD}

For the purpose of this study, the FundMyHome platform is referred to. This platform is Malaysia's first and only property crowdfunding platform that serves to support homeownership. The FundMyHome platform is a privately operated property crowdfunding platform of which the operating mechanism is regulated by the Securities Commission of Malaysia. At present, this platform has more than 7,000 registered users, with about 20 successful applicants who are currently using this property crowdfunding platform as an alternative financing scheme for supporting their homeownership (Idris, 2019). Applicants who successfully 
Hon-Choong Chin, Sheelah Sivanathan, Goh Hong Lip \& Low Choon Wei

First-Time Homebuyers' Interest in Using Property Crowdfunding as An Alternative Financing Option

obtained the required financial support needed to only pay $20 \%$ of the house's price. The applicants are not be tied down to instalment repayments for a period of five years. After five years, the applicants will be given two options, which are (i) retain their ownership, or (ii) sell the property. For the first option, the applicants are required to look for their own financial support to pay the $80 \%$ house price in the platform, in order to secure their homeownership. For the second option, applicants are required to bear costs involved in selling the property, and can enjoy their portion of the gain from selling the property only after paying back the associated costs of the property to the crowdfunding platform.

This study is exploratory in nature, given the fact that utilising property crowdfunding in supporting homeownership is a novel application. This study employed a qualitative interview to probe the respondent's understanding and perceptions about property crowdfunding as an alternative financing option for homebuyers. Using qualitative interviews in this study is expected to provide new information and insights on the adoption of the property crowdfunding platform, and will contribute to our knowledge pertaining to the topic.

A total of thirty-two (32) first-time homebuyers (coded with R1 to R32) were identified during their visit to a local property fair and exhibition centre in Kuala Lumpur. In order to ensure that the interviewees were qualified for our study, the respondents were screened with three questions, (i) if they owned any property; (ii) their income range and (iii) if they had the intention to purchase a property over the next 5 years. The rationale of the first screening question was to ensure the recruited respondents were first-time homebuyers. Subsequently, the second question aimed to ensure that the targeted respondents were users of the property crowdfunding based on their income levels, and lastly, the third question implied if the respondents were rigorously looking for financial options for their homeownership over the 5 year period.

The interviews were recorded and transcribed. The thematic content analysis was used to identify, analyse, organise, describe, and report themes derived from the transcripts (Braun \& Clarke, 2006). The codes and themes had been derived independently by two researchers, with line-by-line coding of the interview transcripts. A rigorous discussion was conducted amongst the researchers for reaching to an affirmative agreement on the identified codes and themes.

\section{FINDINGS}

In total, $46.9 \%$ of the respondents were male. The majority of them ranged between 24 to $30(46.9 \%)$ years of age, and the remaining were above the age of 30. Furthermore, $87.5 \%$ had a household size of 5 or less. The majority of our respondent's profile were young and with a low household size. This was not surprising, as our targeted respondents were first-time homebuyers who were just 
establishing their family, and looking forward to owning property. In terms of income level, almost $84.4 \%$ of our respondents earned less than or equivalent to RM5,000 and the remaining earned between RM5,001 - RM10,000.

In terms of house ownership, none of the interviewees owned any property at the time of the interview. A total of $62.5 \%$ of the interviewees stayed with their family members, and $31.3 \%$ were renting a house, and the remaining $6.3 \%$ are room tenants. The majority of the interviewees $(68.8 \%)$ were seeking to purchase the house for their own dwelling, meanwhile that $25.0 \%$ were looking for an investment opportunity. The remaining $6.3 \%$ were seeking property for personal dwelling or as an investment. Almost $53.1 \%$ of the interviewees were willing to jointly own their property with their family members and spouse, while, $46.9 \%$ had a strong intention to become sole proprietors.

The following sub-sections are presented according to the findings of this study. The findings have been arranged accordingly to correlate to the identified themes, into three sub-sections, (i) prior knowledge of property crowdfunding, (ii) factors which stimulate a homebuyer's interest to use property crowdfunding, and (iii) barriers which hinder homebuyers from using property crowdfunding.

\section{Knowledge on Property Crowdfunding Platform}

In general, $66 \%$ of the respondents $(n=21)$ acknowledged that they were not aware of the term "property crowdfunding". Interestingly, $67 \%$ of the respondents had heard about the FundMyHome platform. Furthermore, those who responded with awareness about property crowdfunding seemed to associate property crowdfunding with the FundMyHome platform. They tended to highlight the mechanism of FundMyHome while explaining their interpretation of property crowdfunding to the researchers. For instance, as noted by R10 "....it means that they are people who invest in our property with a small pool of funds.....so that we can own the house by paying only $20 \%$. The anonymous investors will fund the remaining $80 \% "$. None of the interviewees defined the term from its original operating mechanism and definition. This implied that the public may have misconceptions about property crowdfunding, as the FundMyHome platform actually operates on the basics of property crowdfunding. A plausible explanation is that the public awareness on property crowdfunding is low. The awareness of property crowdfunding is due to the introduction of the FundMyHome platform.

Despite their awareness about property crowdfunding, we were particularly interested in how the homebuyers perceived the FundMyHome platform. Despite the operating mechanism of the platform, interviewees tended to link the platform with government efforts in promoting affordable housing. The statement "supported by government", "financial support from government", "government to reduce financial burdens" and "a loan provided by government to homebuyers" were frequently mentioned by the interviewees. The tendency of 
Hon-Choong Chin, Sheelah Sivanathan, Goh Hong Lip \& Low Choon Wei

First-Time Homebuyers' Interest in Using Property Crowdfunding as An Alternative Financing Option

interviewees to associate the FundMyHome platform with the government can be attributed to the fact that the property crowdfunding had been highlighted in the government's Budget plan 2019. Additionally, the FundMyHome platform was officially launched by the Prime Minister (Tan, 2018), and was supported by the government by providing aid to first-time homebuyers to use the platform for homeownership purposes (Idris, 2019). Thus, it is not surprising that our respondents tended to perceive the platform as a government initiative and strategy to support homeownership among first-time homebuyers.

\section{Factors which contribute to the use of the platform}

Only $21.9 \%(n=7)$ of interviewees acknowledged that they were considering using property crowdfunding as an alternative financing option for supporting their homeownership. The Government's role in property crowdfunding is one of the motivators which stimulate the homebuyer's interest to use property crowdfunding. As highlighted by one of the interviewees, "...the government supports this scheme...the risk can be lowered, and I think is worth to try..." (R31). Also, "...Guaranteed by the government and there must be a fund supported by the government for helping the homebuyers to purchase the property after 5 years..." (R28). This indicated that the government's involvement in property crowdfunding will further enhance the public's confidence in property crowdfunding, and stimulate the homebuyer's interest to use property crowdfunding as an alternative financing option.

Additionally, the advantage of delaying the monthly instalment period is another attractive point for property crowdfunding. Interviewees tended to perceive that the delay in paying the monthly instalment will likely reduce their financial burden and prompt them to opt for this option to own their home over the next 5 years. For instance, as revealed by one interviewee, "...buyers do not need to worry about the monthly instalments, at least for the first five years..."(R10).

Nonetheless, property crowdfunding has been perceived as a replacement financial scheme to that of the traditional housing loan offered by banks. As mentioned by R29, "...If I cannot get a loan from the bank, I may consider it." This was supported by other interviewees, who considered property crowdfunding as a replacement financial scheme for those who cannot meet bank requirements (R31). As an alternative financial option, the public tended to perceive it as a replacement financial scheme, or serve as the last option as mentioned by R32, "...I will put this as the last option..."

\section{Barriers that hinder the usage of the platform}

On the other hand, interviewees who were concerned about the trustworthiness of the platform could prevent them from using property crowdfunding as an alternative financing option. For instance, as noted by R31, "...I would not use it. 
PLANNING MALAYSIA

Journal of the Malaysia Institute of Planners (2021)

I do not really trust the platform...". It is also argued that the platform only "benefits the investors and developers" (R13) and "...it seems to be speculative as it will contribute to price escalation..." (R30). Along with this argument, the interviewees highlighted the importance of a clear agreement in safeguarding those using property crowdfunding to fund their homeownership. As stated by the respondent, "...there needs to be a clear agreement that both parties (the homeowner and the platform owners) will not only benefit but also share the potential risks associated with the mechanism of the platform..." (R27)

The uncertainty and risks associated with the platform is another barrier that hinders the usage of property crowdfunding in supporting homeownership. Although homebuyers may enjoy a five (5) year period of time without commitments toward the housing loan, however, homebuyers were still concerned about what would happen to them after five years. As noted by R26, "...I am not certain if I am able to save enough money for the balance or get another institution to provide a financial scheme for supporting me to pay for the ownership after five years...". In other words, homebuyers who opted for the current property crowdfunding faced the risk of losing their homeownership. This will definitely offset the benefits of using property crowdfunding. As mentioned by R32, "Many uncertainties. I don't believe we can own a home for free. The after five years scenario can be worse, as we may lose our house if we cannot get the loan to support our purchase. What is the point of the five years' timeframe, when you have the risk of losing the ownership after five years" Alongside with this concern, the term "insecure", "not guaranteed", "losing", "actual cost maybe higher", and "jeopardise the interest of homebuyers" were mentioned by the interviewees.

The third theme that emerged from the barriers that hindered the usage of property crowdfunding was related to the housing product offered by the platform. At present, the FundMyHome users have limited choices in term of housing products, of which they are limited in terms of choices listed on the platform. This further discourages interested and committed first-time homebuyers from using the platform, as they are unable to refer to the current platform for funding their preferred housing product, which is not listed on the platform. As mentioned by R29, "...we need to subject to the product listed on the platform, and there are limitations in terms of the product itself, especially at my preferred location". Thus, it is not only the limited product availability but, the location for the housing product which is also a concern for the interviewees.

\section{CONCLUSION}

This study aimed to explore first-time homebuyer's interest to use property crowdfunding as an alternative financing option. A series of interviews had been conducted to probe first-time homebuyer's knowledge and understanding of property crowdfunding. Our finding indicated that the public had limited 
Hon-Choong Chin, Sheelah Sivanathan, Goh Hong Lip \& Low Choon Wei

First-Time Homebuyers' Interest in Using Property Crowdfunding as An Alternative Financing Option

knowledge of property crowdfunding. They had a better understanding of the financing mechanism of the platform, whereby $20 \%$ was paid by the homebuyers, and $80 \%$ was supported by the platform itself. They had a perceived misunderstanding on the government's role in the operating of the property crowdfunding platform in Malaysia. Essentially, the public will likely opt for property crowdfunding if it is supported by the government, as it may potentially reduce the associated financial burden, which is the last financial option after traditional housing loans offered by banks. On the other hand, homebuyers had trust issues, uncertainties, and a high-risk avoidance factor, as well as highlighted limited housing products provided by the property crowdfunding financing scheme.

The results suggested that an additional educational campaign is required, essentially, the concept of crowdfunding, and how it can be utilised and incorporated in our daily activities, rather than employed as an alternative financial solution for business activities. Moreover, although the platform is supported by the government, nonetheless, the misunderstanding on the government's role needs to be clarified. In terms of the platform's mechanism, policy makers and platform operators need to focus on lowering the uncertainty and risks associated with the platform's operation. Initiatives such as a better risksharing mechanisms between the investors and homebuyers, and the deposit guarantee scheme that protects homebuyers from financial risks can contribute toward lowering the uncertainty and risks faced by the homebuyers. To address the limited choice of products, the variety of products need to diversified, and should not be limited to those listed on the platform.

\section{ACKNOWLEDGEMENTS}

This study was funded by Universiti Tunku Abdul Rahman via its internal funding scheme - UTAR Research Fund with the project number of IPSR/RMC/UTARRF/2019-C1/02

\section{REFERENCES}

Ahlers, G. K., Cumming, D., Günther, C., \& Schweizer, D. (2015). Signaling in equity crowdfunding. Entrepreneurship Theory and Practice, 39(4), 955-980

Asian Institute of Finance (2017), Crowdfunding Malaysia's Sharing Economy: Alternative Financing for Micro, Small, and Medium Enterprises, Asian Institute of Finance, Kuala Lumpur.

Braun, V. \& Clarke, V. (2006). Using thematic analysis in psychology. Qualitative Research in Psychology 3:2, 77-101.

Cohen, J. (2016). A Study on the History and Functionality of Real Estate Crowdfunding, Joseph Wharton Research Scholars. Retrieved February, 1, 2019, from http://repository.upenn.edu/joseph_whraton_scholars/19

Hervé, F., Manthé, E., Sannajust, A. \& Schwienbacher, A. (2017). Determinants of Individual Investment Decisions in Investment-Based Crowdfunding, Retrieved 
PLANNING MALAYSIA

Journal of the Malaysia Institute of Planners (2021)

February,1, 2019, from https://papers-ssrncom.access.library.unisa.edu.au/sol3/Delivery.cfm/SSRN ID2746398 code301672.pdf?1

Hing, Y. K., \& Singaravelloo, K. (2018). Impediments to home ownership: perception of low and middle-income tenants in Selangor. Planning Malaysia, 16(3), 357-368.

Idris, A.N. (21 Feb 2019). Housing ministry launches scheme to aid first-time homebuyers. The Edge Financial Daily. Retrieved December 13, 2019, from http://theedgemarkets.com/article/housing-ministry-launches-scheme-to-aidfirsttime-homebuyers

Kamal, E. M., Lai, K. S., \& Yusof, N. A. (2020). The low-middle income housing challenges in Malaysia. Planning Malaysia, 18(1), 102-117.

Lowies, B., Viljoen, C. \& McGreal, S. (2017). Investor perspectives on property crowdfunding: evidence from Australia. Journal of Financial Management of Property and Construction, Vol. 22 No. 3, pp. 303-321.

Maarbani, S. (2015). Real estate crowdfunding: the digital evolution of real estate funding and investment. PricewaterhouseCoopers, Sydney.

Massolution (2015), 2015CF-Crowdfunding Industry Report, Massolution.

Mollick, E. (2014). The dynamics of crowdfunding: An exploratory study, Journal of Business Venturing, 29(1) 1-16

Mokhtarrudin, A., Masrurah, I. M. K., \& Muhamad, S. C. R. (2017). Crowdfunding as a funding opportunity for youth start-ups in Malaysia. Pertanika Journal of Social Sciences \& Humanities, 25, 139-154.

Miller, D. (2015). Crowdfunding Commercial Real Estate - the New Disruptor? Retrieved February,1, 2019, from http://knowledge.wharton.upenn.edu/article/i scrowd-sourced-funding-for-commercial-real-estate-the-next-big-disruptor/.

Ministry of Finance (2018). Budget 2019. Retrieved February,1, 2019, from http://www.treasury.gov.my/pdf/budget/speech/bs19.pdf

Mohd Yusof, R., Mohd Khan, S. J., M Yusuf, F., \& Abdul Majid, N. H. (2019). Bridging the supply and demand gap for affordable home ownership in Malaysia: the roles of government and financial institutions. Planning Malaysia, 17(1), 160-175.

Montgomery, N., Squires, G., \& Syed, I. (2018). Disruptive potential of real estate crowdfunding in the real estate project finance industry: A literature review, Property Management, 36(5), 597-619

Ordanini, A., Miceli, L., Pizzetti, M., \& Parasuraman, A. (2011). Crowd-funding: transforming customers into investors through innovative service platforms, Journal of Service Management, 22(4), 443-470.

Osman, M. M., Zainudin, F. E., Rabe, N. S., Hitam, M., \& Ponrahono, Z. (2020). Challenges and ownership issues facing by low (B40) and medium income group (M40) in Selangor. Planning Malaysia, 18(3), 218-228.

O’ Roarty, B., McMahon, S., Martin, R., Marx, S. \& Craddock, P. (2016). Real estate crowdfunding: gimmick or game changer? Investment Property Forum, 27.

Schweizer, D. \& Zhou, T. (2016). Do principles pay in real estate crowdfunding? The Journal of Portfolio Management, 43 (6) 120-137

Sigar, K. (2012). Fret no more: inapplicability of crowdfunding concerns in the internet age and the JOBS Act's safeguards, Administrative Law Review, 64(2), 473 - 506. 
Hon-Choong Chin, Sheelah Sivanathan, Goh Hong Lip \& Low Choon Wei

First-Time Homebuyers' Interest in Using Property Crowdfunding as An Alternative Financing Option

Ramsey, Y.A., (2012). What the heck is crowdfunding Business people, November, pp. 54.

Tan, V. (04 Nov 2018). PM launches FundMyHome scheme to help first time home owners. The Star. Retrieved December 13, 2019, from http://thestar.com.my/news/nation/2018/11/04/pm-launches-fundmyhomescheme-to-help-first-time-home-owners

Vogel Jr, J. H., \& Moll, B. S. (2014). Crowdfunding for real estate. The Real Estate Finance Journal, Summer/Fall, 5-16.

Yusof, R. M., Aliyu, S., Khan, S. J. M., \& Majid, N. H. A. (2019). Supply overhang of affordable homes: a survival analysis on housing loans application. Planning Malaysia, 17(1), 250-266.

Received: $12^{\text {th }}$ July 2021 . Accepted: $17^{\text {th }}$ Sept 2021 